\title{
Effect of Genotype and Seasons on Semen Characteristics of Three Indigenous Cock Types in the Semi Arid Zone of Nigeria
}

\author{
Adamu, $\mathbf{J}^{1}$, Dauda, $\mathbf{A}^{2^{*}}$, Abbaya, H. $\mathbf{Y}^{3}$ \\ ${ }^{1}$ Department of Animal Science University of Maiduguri, Department of Animal Science, Nigeria \\ ${ }^{2}$ Department of Animal Science University of Calabar, Nigeria \\ ${ }^{3}$ Department of Animal Production Adamawa State University Mubi, Nigeria.
}

*Corresponding Author: Dauda, A, Department of Animal Science University of Calabar, Nigeria. Email: ayubadauda87@gmail.com

\begin{abstract}
The effects of seasons and genotype on semen characteristics of three indigenous cocks types in semi arid zone of Nigeria were assessed. Fifteen (15) local breeder cocks at maturity comprising three strains of indigenous cocks (5 Frizzled, 5 Normal feathered and 5 Naked Neck) were obtained from local farmers in the study area and were used for the study. This employed a $3 x 4$ factorial in a completely randomized design. Semen sample were collected from September 2016 to August 2017 by abdominal massage method, and were assessed for semen colour, semen volume, semen $\mathrm{pH}$, and by routine laboratory methods for semen concentration, sperm motility, sperm abnormality, percent dead sperm cells. The highest mean value of semen volume $(0.45 \mathrm{ml})$ was obtained in frizzle feathered cocks while the lowest mean value of $(0.31 \mathrm{ml})$ was obtained in the naked neck cock. Coefficient of variability was highest in semen volume and ranged from $29.77 \%$ in the normal feathered to $43.69 \%$ in the frizzle feathered cock. The lowest variable semen characteristics were $\mathrm{pH}$ which showed percentage variability that ranged from $4.25 \%$ in the naked neck to $6.13 \%$ in the normal feathered cock. Coefficient of variation for percent dead sperm cells, semen concentration and percent abnormality values ranges between 12.67 and $15.60 \%$. Genotype had a significant $(p<0.05)$ effect on semen volume with frizzle feathered having the highest value of $0.48 \pm 0.02 \mathrm{ml}$ followed by the normal and naked neck cock with corresponding values of $0.33 \pm 0.01 \mathrm{ml}$ and $0.30 \pm 0.01 \mathrm{ml}$. Semen colour, $\mathrm{pH}$, motility, concentration, percent dead sperm cells and abnormality were not significantly $(p>0.05)$ affected by genotype of bird. Season of year significantly $(p<0.05)$ affected all the semen characteristics. The results indicated that for semen volume, early dry season had the highest mean value which is significantly different from the mean values obtained in the late dry, early rainy and late rainy season, which are statistically similar. The semen colour showed no significant $(p>0.05)$ difference in the early dry, late dry and early rainy season but these seasons were significantly $(p<0.05)$ higher in colour intensity than the late rainy season. The intensity of semen colour decrease with the rains. Semen $\mathrm{pH}$ was nearly neutral in all the season except early rainy season which tended towards acidity and was significantly different from the other seasons. There were no statistically significant $(p>0.05)$ interaction effects on almost all semen characteristics except semen volume. Semen volume was the same in late dry and late rainy seasons which was significantly different $(p<0.05)$ for early dry and early rainy in the normal feathered and naked neck genotype. The combined effects of season and genotype had no significant effect on semen volume in the frizzled feathered cock. The non-significant ( $p>0.05)$ effect of the combined factors of season and genotype on the semen volume of the frizzled cock demonstrates the robostness or stability of the frizzle cock in terms of ejaculates volume all year round. From the results of this study, it is recommended that the frizzle feathered cock should be the genotype of choice for genetic upgrading in the region because of its stability in semen characteristics in all the seasons of the year.
\end{abstract}

Keywords: Indigenous cocks, Genotype, Seasons Semen Characteristics

\section{INTRODUCTION}

Indigenous chickens are widely distributed in the rural areas of tropical and sub-tropical countries where they are kept by the majority of the rural poor. Indigenous chickens in Africa are general hardy, adaptive to rural environments, survive on little or no inputs and adjust to fluctuations in feed availability Gueye (2003). Great genetic resources embedded in the indigenous poultry await full exploitation that will provide basis for genetic improvement and diversification to produce breeds that are adapted to local conditions for the benefit of farmers in developing countries (Horst, 1988; Sonaiya et al., 1999). The Nigerian indigenous chickens 
have been reported to have many advantageous gene complexes that could be harnessed in the development of meat or egg type chicken suitable for use in the tropics (Machebe and Ezekwe, 2004). Among these single major genes are the Naked necked, Frizzled and Normal feathered. According to Ibe (1998) the Frizzled and Naked neck genes are tolerant to heat stress, disease resistance and possess increase production capacity. The assessment of semen quality characteristics of poultry birds gives an excellent indication of their reproductive potential and has been reported to be a major determinant of fertility and subsequent hatchability of eggs (Peters et al., 2004). The semen of the domestic fowl according to Hafez (1978), varies from a dense opaque suspension to a watery fluid with a relative high density. He further stated that the differences in volumes and semen concentration of the domestic fowl semen depends largely on the relative contribution of the various reproductive glands, the number of spermatozoa that could be obtained from a breed/strain and the extent to which the genetic potentials can be exploited. It is important to note that many researchers have worked on semen production and quality on a variety of poultry breeds and strains. Breed and seasonal differences in semen production of cocks was reported by Saeed and Al-Soudi (1975) while Egbunike and Oluyemi (1979) showed that breed and time of semen collection affects cock semen. Omeje and Marine (1990) observed that significant genotype differences and season affect semen characteristics of cocks.

Seasonal variation in semen quality of domestic fowl has been documented (Santiago-Moreno et al., 2011). McDaniel et al. (1996) reported that an ambient temperature of $>31^{\circ} \mathrm{C}$ depressed sperm motility, viability and fertilization potential. Even environmental temperature at ejaculation has an important effect on avian sperm motility (Ashizawa and Sano 1990; Wishart and Wilson 1999). It is necessary to evaluate the reproductive performance of tropical birds so as to help in selecting those males that could be used in breeding programmes and for sustainable meat and egg production in Nigeria. There are differences between species in the volume of semen concentration and total number of spermatozoa in an ejaculate. Differences in volume and semen concentration depend largely on the relative contribution of the various reproductive glands (Hafez ,1987).
There is paucity of information on the effects of genotype and season on semen characteristics of the local cocks in the semi arid zone of Nigeria. The aim of this study was to determine the effect of genotype and season on semen characteristic of three indigenous cock types in the semi arid zone of Nigeria.

\section{Materials ANd Methods}

Fifteen (15) local breeder cocks at maturity comprising three strains of indigenous cocks (5 Frizzle, 5 Normal feathered and 5 Naked Neck) were obtained from local farmers within the state and used for the study. They were sexually matured cocks of about $14-18$ months of age. The experimental birds were acclimatized for two weeks during which they were monitored and screened. Each cock was tagged for ease of identification. The study was conducted during the rainy and dry seasons, which were further subdivided into early dry season (OctoberDecember) late dry season (January - March) and early rainy season (April - June) and late rainy season (July - September). The cocks were housed individually in $1.0 \mathrm{ft}$ conventional battery cage, and were fed Top feeds ${ }^{\circledR}$ growers mash from premier feed mills limited Nigerian throughout the experimental period. The grower mash contained $18 \%$ crude protein and Metabolisable energy of $2900 \mathrm{kcal} / \mathrm{kg}$. Feed and water were given fresh and in ad- libitum throughout the study period. All birds were trained to produce semen prior to actual semen collection. This was considered necessary not only for effective semen collection but also to make the birds familiar with the semen collector. Semen samples collected from the birds were accomplished by abdominal massage technique (Etches, 1996). The cloaca of each bird was massaged by the application of a slight finger to generate pressure to allow the papillae release the semen. This was then milked down into a graduated collection tube. Semen samples collected were subjected to microscopic examination and physical evaluation.

\section{Semen Collection and Evaluation}

A total of 497 semen ejaculates was collected from the cocks by the abdominal message technique as described by Etches (1996). Semen from all cocks were collected between 08:00 am and 10:00 am during each of the season throughout the experimental period. Each bird responded to massage by partial aversion of the cloaca, and semen was collected from the ventral lip of the vent into a tube maintained at $\pm 38-40^{\circ} \mathrm{C}$. 
Individual ejaculates were collected into $1.8 \mathrm{ml}$ graduated collection tube to record the volume of the semen per ejaculate. During collection the semen tube was maintained at $38-40^{\circ} \mathrm{C}$ in a thermo flask. The semen was assessed for volume using the calibrations on the collecting vials. Volume was record to the nearest $0.1 \mathrm{ml}$. Thereafter, sperm motility was immediately evaluated. Motility was expressed as the percentage of motile sperm with moderate to rapid progressive movement (Cheng et al., 2002). The semen collected was subject to microscopic examinations and physical evaluations. A drop of undiluted semen was placed on a glass slide, cover slipped and examined under the field microscope at $x 100$ magnification. The vial was immersed into water flask containing water maintained at $40^{\circ} \mathrm{C}$ for further semen evaluation. Semen colour was visually observed from a transparent collecting vials and expressed as creamy, milky or watery, and scored as 3, 2 or 1, respectively as described by Kabir et al. (2007). The semen pH was obtained using the $\mathrm{pH}$ meter strip. Colour change on the strip will be read using the $\mathrm{pH}$ meter (Chemo craft $\AA$ ) as indicated by the manufacturer.

Percent dead spermatzoa and the sperm abnormalities were obtained using stained slides from each of the semen samples. The stained slides were prepared using the eosin-nigros in vital technique as described by Sekoni et al. (1981). A drop of the semen sample was placed on one end of the slide and a drop of the eosinnigrosin vital stain was added and both was gently mixed. The mixture was then collected using the edge of a clean dry slide, and a smear made on a fresh slide. Then the stained slide was left to dry. The percentage dead sperm cell was calculated from the stained slides as described by Esteso et al. (2006). The slide was viewed under the light microscope at $\mathrm{x} 400$ magnification and 100 sperm cells were counted per slide for both live and dead spermatozoa. The dead sperm cells stained with the eosin dye while the live cells repelled the stain. This was repeated to ensure accuracy and the average was taken. Sperm abnormalities were studied from the stain slides under the light microscope at $x 1000$ magnification using the oil immersion. Concentration of the spermatozoa was determined as described by Rekwot et al. (1994). The cells were counted using the red blood cell counting chamber of the haemocytometer, diagonally from top left to right bottom in 5 large squares from the 25 large squares. The concentration of sperm per $\mathrm{ml}$ was found using the formula:

$$
\mathrm{C}=50,000 \times \mathrm{N} \times \mathrm{D}
$$

Where $\mathrm{C}=$ concentration of sperm per volume (ml), N= Number of spermatozoa counted, $\mathrm{D}=$ Dilution rate.

\section{Experimental Design and Statistical Analysis}

The experiment involved a $3 \times 4$ factorial in a completely randomized design. This generated twelve (12) treatment combinations and each treatment combination was replicated three times. Data generated was subjected to one way analysis of variance (ANOVA) and the following linear statistical model was entertained.

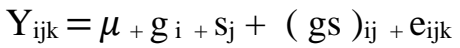

Where

$\mathrm{Y}_{\mathrm{ijk}}=$ single observation

$\mu=$ overall mean

$\mathrm{g}_{\mathrm{i}}=$ fixed effect of the $\mathrm{i}^{\text {th }}$ genotype of bird ( $\mathrm{i}=1,2$, 3)

$\mathrm{s}_{\mathrm{j}}$ = fixed effect of the $\mathrm{j}^{\text {th }}$ season $(\mathrm{j}=1,2,3,4)$

$(\mathrm{gs})_{\mathrm{ij}}=$ effect of interaction between genotype and season

$\mathrm{e}_{\mathrm{ijk}}=$ random residual error .

\section{RESULTS}

Table1. Effect of Genotype on Semen Characteristic of Three Indigenous Cocks

\begin{tabular}{|l|l|l|l|l|l|l|l|}
\hline Genotype & $\begin{array}{l}\text { Volume } \\
(\mathrm{ml})\end{array}$ & Colour & PH & Motility(\%) & Dsc (\%) & $\begin{array}{l}\text { Concentration } \\
\left(10^{9} / \mathrm{ml}\right)\end{array}$ & $\begin{array}{l}\text { Abnormality } \\
(\%)\end{array}$ \\
\hline NF & $\begin{array}{l}34 \pm 0.01^{\mathrm{b}} \\
\text { ( }\end{array}$ & $2.07 \pm 0.05$ & $7.05 \pm 0.06$ & $55.52 \pm 1.32$ & $44.58 \pm 1.31$ & $4.16 \pm 0.14$ & $23.80 \pm 0.91$ \\
\hline FF & $\begin{array}{l}0.48 \pm \\
0.02^{\mathrm{a}}\end{array}$ & $2.09 \pm 0.06$ & $7.06 \pm 0.06$ & $57.06 \pm 1.40$ & $42.66 \pm 1.40$ & $4.39 \pm 0.13$ & $23.86 \pm 0.90$ \\
\hline NA & $\begin{array}{l}0.31 \pm \\
0.01^{\mathrm{b}}\end{array}$ & $2.06 \pm 0.08$ & $7.12 \pm 0.05$ & $56.19 \pm 1.42$ & $43.76 \pm 1.43$ & $4.39 \pm 0.12$ & $23.47 \pm 1.06$ \\
\hline
\end{tabular}

$a, b=$ Means in the same column with different super scripts differ $(p<0.05)$ significantly. NF= Normal feather, $F F=$ Frizzle feather, $N A=$ Naked neck. Dsc= percent dead sperm cell . 
Effect of Genotype and Seasons on Semen Characteristics of Three Indigenous Cock Types in the Semi Arid Zone of Nigeria

\section{Effect of Season of Year on Semen Characteristics}

Table 2. Presents the effects of season of year on semen characteristics of three indigenous cocks in semi arid zone of Nigeria. Season of year significantly $(\mathrm{p}<0.05)$ affected all the semen characteristics. The results indicated that for semen volume, early dry season had the highest mean value which is significantly different from the mean values obtained in the late dry, early rainy and late rainy season, which are statistically similar. The semen colour showed no significant (p>0.05) difference in the early dry, late dry and early rainy season but these seasons were significantly $(\mathrm{p}<0.05)$ higher in colour intensity than the late rainy season. The intensity of semen colour decrease with the rains. Semen $\mathrm{pH}$ was nearly neutral in all the season except early rainy season which tended towards acidity and was significantly different from the other seasons.

Individual motility (\%) was lowest in the early dry season while the highest motility occurred in the late dry season whose value was not significantly different from early rainy and late rainy seasons. Lowest semen concentration was observed in the late dry season (when motility was highest). while highest concentration was early rainy season, although the values were similar $(p>0.05)$ to the concentration obtained for early dry and late rainy seasons. There was no particular trend in the \% abnormality among the seasons but the highest significant abnormality occurred in the late rainy season.

\section{The Interaction Effect of Season and Genotype on Semen Characteristics of the Three Indigenous Cocks}

The combined effect of season and genotype on the semen characteristics of the indigenous cocks is presented in Table 3. There were no statistically significant ( $p>0.05)$ interaction effects on almost all semen characteristics except semen volume. Semen volume was the same in late dry and late rainy seasons which was significantly different $(\mathrm{p}<0.05)$ for early dry and early rainy in the normal feathered and naked neck genotype. The combined effects of season and genotype had no significant effect on semen volume in the frizzled feathered cock.

Table2. Effects of Season of Year on Semen Characteristic of Three Indigenous Cocks

\begin{tabular}{|l|l|l|l|l|l|l|l|}
\hline Season & Vol $(\mathrm{ml})$ & Colour & $\mathrm{pH}$ & $\operatorname{Mot}(\%)$ & Dsc $(\%)$ & Conc $\left(x 10^{9} / \mathrm{ml}\right.$ & Abnorm \\
\hline Early Dry & $0.45 \pm 0.04^{\mathrm{a}}$ & $2.09 \pm 0.05^{\mathrm{ab}}$ & $7.08 \pm 0.07^{\mathrm{ab}}$ & $52.21 \pm 0.98^{\mathrm{b}}$ & $47.49 \pm 1.00^{\mathrm{a}}$ & $4.71 \pm 0.14^{\mathrm{a}}$ & $19.00 \pm 1.06^{\mathrm{c}}$ \\
\hline Late Dry & $0.36 \pm 0.03^{\mathrm{b}}$ & $2.02 \pm 0.05^{\mathrm{ab}}$ & $7.27 \pm 0.07^{\mathrm{a}}$ & $59.78 \pm 1.12^{\mathrm{a}}$ & $40.21 \pm 1.13^{\mathrm{b}}$ & $3.75 \pm 0.01^{\mathrm{b}}$ & $21.99 \pm 0.60^{\mathrm{c}}$ \\
\hline EarlyRainy & $0.32 \pm 0.02^{\mathrm{b}}$ & $2.21 \pm 0.69^{\mathrm{a}}$ & $6.88 \pm 0.08^{\mathrm{b}}$ & $55.73 \pm 2.09^{\mathrm{ab}}$ & $44.18 \pm 2.11^{\mathrm{a}}$ & $4.73 \pm 0.16^{\mathrm{a}}$ & $24.93 \pm 0.65^{\mathrm{b}}$ \\
\hline Late Rainy & $0.36 \pm 0.03^{\mathrm{b}}$ & $1.95 \pm 0.12^{\mathrm{b}}$ & $7.07 \pm 0.06^{\mathrm{ab}}$ & $57.23 \pm 1.60^{\mathrm{a}}$ & $42.70 \pm 1.60^{\mathrm{ab}}$ & $4.09 \pm 0.14^{\mathrm{ab}}$ & $28.91 \pm 1.02^{\mathrm{a}}$ \\
\hline
\end{tabular}

$a b c=$ means with differ superscript within the same column differ significantly $(p<0.05)$. Early, vol $=$ semen volume, $\mathrm{pH}=$ semen $\mathrm{pH}$, mot =sperm motility, Dsc $=$ Percent dead sperm cells and abnorm $=$ abnormality

Table3. Combined Effect of Season of Year and Genotype on Semen Characteristics of Three Indigenous Cock

\begin{tabular}{|l|l|l|l|l|l|l|l|l|l|l|l|l|l|}
\hline & & Normal & & & Frizzle & & & & & Naked neck & & \\
\hline $\begin{array}{l}\text { Semen } \\
\text { Parameter }\end{array}$ & ED & LD & ER & LR & ED & LD & ER & LR & ED & LD & ER & LR & \pm SEM \\
\hline Volume & $0.32^{\mathrm{a}}$ & $0.39^{\mathrm{b}}$ & $0.29^{\mathrm{a}}$ & $0.34^{\mathrm{b}}$ & $0.45^{\mathrm{a}}$ & $0.61^{\mathrm{a}}$ & $0.38^{\mathrm{a}}$ & $0.47^{\mathrm{a}}$ & $0.31^{\mathrm{a}}$ & $0.35^{\mathrm{b}}$ & $0.28^{\mathrm{a}}$ & $0.28^{\mathrm{b}}$ & 0.02 \\
\hline Colour & 1.96 & 2.12 & 2.23 & 1.97 & 1.99 & 2.14 & 2.07 & 2.30 & 2.13 & 2.03 & 2.34 & 1.76 & 0.04 \\
\hline pH & 7.24 & 7.03 & 6.84 & 7.09 & 7.23 & 7.04 & 6.98 & 6.95 & 7.00 & 7.17 & 6.83 & 7.15 & 0.04 \\
\hline Mot & 58.00 & 5.50 & 54.68 & 57.06 & 61.28 & 53.00 & 56.03 & 62.17 & 60.02 & 51.44 & 56.50 & 56.80 & 0.83 \\
\hline Dsc & 42.06 & 48.50 & 45.32 & 42.84 & 38.72 & 45.30 & 43.96 & 37.83 & 39.98 & 40.64 & 43.38 & 43.19 & 0.85 \\
\hline Conc & 3.64 & 4.56 & 4.64 & 3.82 & 3.80 & 4.75 & 4.87 & 4.64 & 3.76 & 4.22 & 4.75 & 4.82 & 0.83 \\
\hline Abnorm & 18.95 & 22.78 & 23.88 & 29.38 & 19.41 & 22.16 & 25.45 & 31.20 & 20.82 & 18.64 & 25.45 & 28.90 & 0.55 \\
\hline
\end{tabular}

$a, b=$ means in the same row with different letters are significantly different $(p<0.05), E D=$ early dry season, $L D=$ late dry season, $E R=$ early rainy season $L R=$ late rainy season. Mot $=$ individual sperm motility, Dsc $=$ dead sperm cells Conc $=$ semen concentration Abnorm $=$ sperm abnormality.

\section{DISCUSSION}

The present investigation agreed with Siudzinska and Lukaszewiez (2008) who confirmed that breed had no significant effect on semen characteristics. Furthermore, the volumes of ejaculate and semen concentrations collected from the breeds used in their study were not significantly different. Long et al. (2010) investigated fresh semen from 8 pedigreed layer lines and found no differences among the poultry lines or strains in terms of semen characteristics. The advanced reasons that the 
non-effect of breed on semen characteristics may be due to the close genetic backgrounds. However, in the present study genotype differences in semen volume was noticed. This seems to agree with the findings of Peters et al. (2008) and Ajayi et al. (2011) who observed differences in strains of Nigerian indigenous cocks in terms of semen volume, concentration and motility. The percent individual sperm motility of 57.06, 56.19 and 55.52 obtained for frizzle feathered, naked neck and normal feather cocks respectively, are lower than the values obtained by Rekwots et al. (2005) and Peters et al. (2008), which values however are higher than those obtained by Ajayi et al. (2014) who reported percent motility of 20 in the frizzle feathered and 40 in the normal feathered cock. These differences are said to be due to the differences in the genetic makeup of the birds.

Significant effect of season on semen characteristics of the indigenous cocks in this Study corroborates the findings of Bah et al. (2001) and Rekwot et al. (2005). The lowest semen volume in the early rainy season relative to the late rainy, early dry and late dry seasons may be due to differences in ambient temperatures among the different seasons. Penfold et al. (2000) and Machebe and Ezekwe (2004) had also earlier implicated ambient temperatures as possible causes of seasonal influence on semen volume of local breeder cocks in the south eastern rain forest of Nigeria. Similar results were obtained by Bah et al. (2001) in Sahel region of Nigeria. The observed differences in the intensity of semen colour among the seasons seems to agree with the findings of Peters et al. (2008) who reported that semen colour of indigenous cocks varied from milky to slightly creamy but disagreed with Ajayi et al. (2014) who reported milky brown for semen colour. These variations may be due to the presence of contaminants (Etches, 1998) or as a results of low semen concentration. The variation in semen concentrations with seasons in the indigenous cocks may be due to the meteorological conditions prevailing during the various seasons rather than management technique. This submission was earlier made by Rekwot et al. (2008) and Bah et al. (2001) who recorded highest semen concentration during the rainy seasons.

The findings that the ejaculates of all the genotype had the highest and lowest values of percent abnormality during the late rainy and early dry season contradicts the findings of Bah et al. (2001) in Sahel cocks and Rekwot et al. (2005) in the Red strain of Shika brown breeders cocks. This difference may be due to changes in season and probably due to difference in the genetic background of the indigenous cocks. Machebe and Ezekwe, (2004) recorded high values for percent abnormality during the rainy season which agreed with the present findings. The seasonal variations in percent non motile sperm as observed in the present study agrees with the findings of Bah et al. (2001) and Rekwot et al. (2005) who showed that the hot dry season affected semen characteristics. The results further indicate that maximum fertility in indigenous cocks for breeding should be obtained during rainy season of the year when semen concentration is high.

The non significant ( $p>0.05$ ) effect of the combined factors of season and genotype on the semen volume of the frizzled cock demonstrates the robostness or stability of the frizzle cock in terms of ejaculates volume all year round. Apart from semen volume, season and genotype are not important factors of consideration in evaluating the semen characteristics of the indigenous cocks found in the semi arid zone of Nigeria.

\section{CONCLUSION}

The semen characteristics of three indigenous types of breeders cocks viz normal feathered naked neck and frizzled feathered in the semi arid region of Nigeria were evaluated in different seasons of the year. Five (5) mature breeder cocks of each genotype were involved in the study and the season was divided into four viz Early dry season, Late dry season, Early rainy season and Late rainy season. Season of the year had significant $(p<0.05)$ effect on all semen characteristics. Genotype of cocks on the other hand, had no significant effect on most of the semen characteristics except semen volume where the frizzle feathered cock exhibited higher semen volume when compared to the normal feathered and naked neck cocks. Similarly the combined effect of season and genotype did not significantly affect the semen variables excepts the frizzle feathered cocks that exhibited high semen volume in early dry and late rainy seasons when compared with late dry and early rainy seasons.

\section{RECOMMENDATIONS}

From the results of this study, it is recommended that the frizzle feathered cock should be the genotype of choice for genetic upgrading in the 
region because of its higher stability in semen characteristics in all the seasons of the year.

Palliative measures are required to offset seasonal effects on semen characteristics to ensure all year round breeding activities in the indigenous poultry sector in the semi-arid region of Nigeria.

Further studies are recommended to investigate the effects of season and genotype on the fertility of the indigenous cocks of the semi- arid region of Nigeria.

\section{REFERENCES}

[1] Ajayi, F. O., Agraviezor, B. O. and Ebogomo, D. (2014). Comparative studies of semen and Haematology quality of Nigeria indigenous and exotic chiken breeds in the humid tropical zone of Nigeria. Global Journal of Bio - Science and Biotechnology 3(2):164 -168

[2] Ajayi, F.O., Agraviezor, B.O. and Ajuogu, P, K. (2011). Semen characteristic of three strains of local cocks in the humid tropical environment of Nigeria. International Journal of Animal Veterinary Advance 3(3): 125 -127

[3] Ashizawa, K and Sano, R. (1990). Effects of temperature on the immobilization and the initiation of motility of spermatozoa in the male reproductive tract of the domestic fowl. Gallus domesticus. Comprehensive Biochemical Physiology. 96(2): 297 -301

[4] Bah, A.S., Chandhari, S. U. R. and Al-Amin, J.D. (2001). Semen characteristics of local Breeder cocks in the Sahel Region of Nigeria. Journal of Resources Medicine Veterinary Pays Tropical. 54(2):

[5] Cheng, F. P., Guo, T. J. (2002). Annual variation in semen characteristics of pigeons (Columba livia). Poultry Science Journal. 81: 1050-1056

[6] Egbunike, C.N. and Oluyemi, J. A. (1979). Comparative studies of the reproductive capacity of Nigerian and exotic poultry breeds. Nigeria Journal of Animal Production., 6: 4757.

[7] Esteso, M .C, Soler, A. J, Fernandez-Santos, M.R, Quintero-Moreno, A.A, Garde,A.A (2006). Functional significance of the sperm head morphometric size and shape for determining freezability in Iberian red deer (Cervus elaphus hispanicus) epididymal sperm samples. Journal of Andrology., 27: 662-670

[8] Esteso, M .C, Soler, A. J, Fernandez-Santos, M.R, Quintero-Moreno, A.A, Garde, A.A (2006). Functional significance of the sperm head morphometric size and shape for determining freezability in Iberian red deer
(Cervus elaphus hispanicus) epididymal sperm samples. Journal of Andrology .27: 662-670

[9] Etches, R.J (1996). Biotechnology and genetic improvement of poultry: Proceedings of the 11th World's Poult. Progr., New Delhi. 1: 295-304.

[10] Etches, R.T., 1998. Reproduction in Poultry. CAB Int., Wallingford, pp: 318.

[11] Gueye, E. F. (2003). Production and consumption trend in Africa. World Poultry. 19: 12-14.

[12] Hafez. E.S.E. (1978). Reproduction in Farm Animals. 2nd Edn., Education Page. Lea and Febiger, Philadelphia, pp: 237.

[13] Horst, P. (1988). Native fowl as reservoir for genomes and major genes with direct and indirect effects on production adaptability. Proceedings of the 18th World Poultry Congress, September 4-9.

[14] Ibe, S.N. (1998). Improving Productive Adaptability of the Nigerian local chicken. Proceedings Silver. Anniv. Conferenceh, NSAP/WASAP, University of Agriculture, Abeokuta. 21-26 March, pp: 460-465

[15] kabir M, Oni, O.O., Akpa, G. N. (2007). Osborne selection index and semen traits interrelationships in Rhode Island Redand White Breeder cocks. International Journal of Poultry Science., 6(12): 999-1002.

[16] Long, J. A. Bongalhardo, D. C, Pelaez, J, Saxena, S. Settar, P. Sullivan, N.P.O. and Fulton, J. E (2010). Rooster semen cryopreservation: Effect of pedigree line and male age on post-thaw sperm function. Journal of Poultry Science. 89(5): 966-973.

[17] Machebe, N.S. and Ezekwe, A, G. (2004). Ejaculate characteristics of three genotypes of local cocks in the humid tropics. Journal of Tropical Agriculture Food and Environmental Extention., 3(2): 33-37.

[18] Omeje S.S. and Marine B. N. (1990). Evaluation of semen characteristics of adult cocks of different genetic background. Theriogenology, 24: 1111-1118.

[19] Penfold L. M. Wild, D. E. Herzog, T.E. Lyngh, W. Ware, L. (2000). Patterns of LH, testosterone and semen quality in the Northern pintail duck. Reproductive. Fertility and Development, 12: $229-235$

[20] Peters S.O., O.D. Shoyebo, B.M. Ilori, M.O. Ozoje, C.O.N. Ikeobi and O.A. Adebambo, ( 2008). Semen Quality traits of seven strains of chicken Raised in the Humid Tropics. International Journal of Poultry Science., 7(10): 949-953.

[21] Rekwot P.I, Oyedipe. E.O, Ehoche, G.W (1994). The effect of feed restriction and realimentation on the growth and reproductive function of Bokoloji bulls. Theriogenology., 42: 287-295. 
[22] Rekwot, P. I Ayo, J.O. Obidi, J.A. Dzenda, T. and Onyeanusi, B. I.(2008). Seasonal variation in seminar characteristics of shikabrown breeders cocks. International Journal of Poultry Science 7(12):1219-1223.

[23] Rekwot,P. I .Abubakar, Y.U.Anyam, A.A.Sekoni, U. O.Jatau, J. and Magaji, S. (2005) . Spermiogram of shikabrown Red breeds cocks paper presented at the Nigeria Veterinary medical Association conference Sokoto November pp:1-10 Reprod Dom Anim. 47(4): 578-583.

[24] Saeed J.M.and Alsoudi, K. A.(1975) . Seasonal variation in semen characteristic of white leghorn. New Hamphire and indigenous chickens in Iran. Br. Journal of Poultry Science -16-91-102

[25] Santiago-Moreno J, Castano C, Toledano-Diaz A,Coloma MA, Lopez-Sebastian A, Prieto, M.T .and Campo, J. L.( 2011). Influence of season on the freezability of free-range poultry semen Reproductive Domio Animal Journal. 47(4): 578-583
[26] Sekoni, V.O, Gustafsson, B.K, and Mather, E.C (1981). Influence of wet fixation, staining techniques and storage time on bull's sperm morphology. Nordisk Veterinaermedicin.,33: 161-166.

[27] Siudzinska, A. and Lukaszewicz, E. (2008). Effect of semen extenders and storage time on sperm morphology of four chicken breeds. Journal of Apply Poultry Resource. 17(1): 101108.

[28] Sonaiya, E.B. Branckaert, R.D.S. and Gueye, E.F. (1999). Research and development options for family poultry. First INFPD/FAO Electronic Conference on Family Poultry. spermatozoa from different avian species. Animal Reproductive Science. 57(3-4): 229-235.

[29] Wishart, G.J, and Wilson, Y.I. (1999). Temperature- dependent inhibition of motility in spermatozoa from different avian species. Journal of Animal Reproductive Science. 57(3-4): 229-235.

Citation: Adamu, J, Dauda, A, Abbaya, H. Y. Effect of Genotype and Seasons on Semen Characteristics of Three Indigenous Cock Types in the Semi Arid Zone of Nigeria. ARC Journal of Animal and Veterinary Sciences. 2019; 5(2):9-15. doi: dx.doi.org/10.20431/2455-2518.0502002.

Copyright: (C) 2019 Authors. This is an open-access article distributed under the terms of the Creative Commons Attribution License, which permits unrestricted use, distribution, and reproduction in any medium, provided the original author and source are credited. 